\title{
PREGNANCY DIAGNOSIS, FETAL QUANTIFICATIONAND GENDER ESTIMATION BY ULTRA-SONOGRAPHY IN EWES
}

\author{
Diagnóstico de gestação, quantificação e sexagem fetal por ultra-sonografia em ovelhas
}

\author{
Lilian Mara Kirsch Dias', José Camisão de Souza², Roberta de Moura Assis ${ }^{3}$, Camila de Moraes Raymundo ${ }^{4}$
}

\begin{abstract}
The objective of this experiment was to evaluate the accuracy of gestation, fetal sexing and quantification diagnoses in ewes. Pregnancy and fetal quantification were diagnosed in 105 ewes at 35 days of pregnancy. For the fetal gender diagnosis sexing diagnose 55 ewes between 49 and 59 days of pregnancy were used. All exams were recorded on DVD for posterior analysis. After birth, lamb sex was recorded to determine fetal sexing precision. Data were analyzed by chisquare $\left(\chi^{2}\right)$ or Fisher's test, with a significance of 0.05 . One hundred percent of pregnancy ultrasound diagnoses were correct. As for the fetal quantification diagnoses, there was an error of $12 \%$. It was possible to diagnose the fetal sex in $87 \%$ of the 69 examined fetuses, and $90 \%$ of these were estimated correctly. The realtime ultrasound diagnoses were not different from the recorded DVD image diagnoses. Therefore, pregnancy diagnosis accuracy may reach $100 \%$, differing from fetal gender estimation and quantification, which are dependent upon other variables such as fetal gender and examiner experience.
\end{abstract}

Index terms: Ovine, fetal sexing, pregnancy diagnosis, ultra-sonography.

\section{RESUMO}

O objetivo deste experimento foi avaliar a acurácia do diagnóstico de gestação, quantificação e sexagem fetal em ovelhas. Foram realizados o diagnóstico de gestação e a quantificação fetal em 105 ovelhas aos 35 dias de gestação. Para o diagnóstico da sexagem fetal foram utilizadas 55 ovelhas com período de gestação entre 49 e 59 dias. As imagens de todos os exames foram gravadas em DVD para permitir posterior análise. Após o nascimento dos cordeiros, os respectivos sexos foram observados para determinar a precisão do exame de sexagem fetal. Os dados foram analisados pelo teste Qui-quadrado $\left(\chi^{2}\right)$ ou Teste de Fisher, com nível de significância de 5\%. Observou-se $100 \%$ de acerto no diagnóstico de gestação pela ultra-sonografia. Quanto ao diagnóstico de quantificação fetal, houve $12 \%$ de erro. Foi possível diagnosticar o sexo fetal em $87 \%$ dos fetos e destes, $90 \%$ estavam corretos. Os diagnósticos em tempo real não foram significativamente diferentes dos diagnósticos feitos após a observação de imagens gravadas em DVD. Portanto, a acurácia do diagnóstico de gestação pode alcançar $100 \%$, diferente da quantificação e sexagem fetal, que dependem de outras variáveis como tipo de gestação e experiência do operador.

Termos para indexação: Ovinos, sexagem fetal, diagnóstico de gestação, ultra-sonografia.

(Received in April 20, 2007 and approved in July 2, 2008)

\section{INTRODUCTION}

Early pregnancy diagnosis and fetal quantification through ultra-sonography contribute to rationalize management and bring financial benefits to ovine production. This method allows non-pregnant ewes or bearing reproductive problems to be culled from the herd, decreasing feed costs. Dantas et al., (2008) moreover, the distinction of single and multiple fetuses allows the breeder to provide a more adequate nutritional management at the end of gestation, optimizing birth weight, lamb weight gain and survival (White et al, 1984; Gearhart et al, 1988; Santos et al, 2004 and 2007b).

Examples of fetal gender determination advantages an improvement in animal acquisition planning and commercialization within the herd, concentrating females in dairy herds and males in beef herds (Haibel, 1990).

The accuracy of fetal gender determination in sheep and goats may vary from 78 to $100 \%$ (Coughbrough \& Castell, 1998; Bürstel et al, 2002; Santos et al, 2005b; Santos et al, 2006) and may be influenced by the presence of multiple fetuses (Bürstel, 2002; Oliveira et al, 2005; Santos et al, 2005 a, b).

\footnotetext{
${ }^{1}$ Veterinarian, MSc. doctoral candidate in Animal Reproduction - Departamento de Reprodução Animal/VRA - Faculdade de Medicina Veterinária e Zootecnia da Universidade de São Paulo/FMVZ - Rua Ibiraúna, 88 - Parque São Domingos - 051121-100 - São Paulo, SP - lilikirsch@yahoo.com.br - under a CAPES scholarship.

2Veterinarian, Ph.D., Professor - Departamento de Zootecnia/DZO - Universidade Federal de Lavras/UFLA - Cx. P. 3037 - $37200-000$ - Lavras, MG jcamisao@ufla.br

${ }^{3}$ Animal Scientist, Master, Doctoral candidate in Animal Production - Departamento de Zootecnia/DZO - Universidade Federal de Lavras/UFLA - Cx. P. 3037-37200-000 - Lavras, MG - betaassis@uol.com.br

${ }^{4}$ Animal Scientist, master student - Departamento de Zootecnia/DZO - Universidade Federal de Lavras/UFLA - Cx. P. 3037 - $37200-000$ - Lavras, MG mila_zoo@yahoo.com.br
} 
Adoption of this technique, especially as a field routine, depends on greater diagnostic precision, especially when there are multiple fetuses, age disparity among fetuses and, most important, the performance of only a single exam, which may contribute to wrong diagnosis (Bürstel, 2002; Santos et al, 2005 a).

This experiment was conducted to evaluate the efficiency of fetal quantification and gender estimation through intra-rectal real-time ultra-sonography examination, performed under field conditions.

\section{MATERIALAND METHODS}

\section{Location}

This Trial was conducted at the sheep unit of the Universidade Federal de Lavras, at Lavras - MG from August to October of 2006. From a total of 105 ewes examined for pregnancy checking, only 55 were used for fetal gender determination. Ewes were restrained for the ultrasound exams in a cage and had their abdomen lifted by a belt to decrease the distance between the uterus and the ultrasound transducer. It was attempted to keep the examining room with as little external light as possible and the ultrasound unit screen at the level of the operator's eye, as recommended by Curran and Ginther (1989).

\section{Ultra-sonography}

Only a single real-time ultrasound exam was performed on each ewe, simulating field exam conditions. A portable ultrasound unit (ALOKA SSD-500, Berger, São Paulo, Brazil) in B-mode, equipped with a linear $5 \mathrm{MHz}$ transducer was used. A plastic stand was adapted to the transducer to facilitate its rectal placement. The transducer and the rectal cavity were generously lubricated with a carboximethylcellulose gel (Gel in shape, Suprimed Indústria e Comércio Ltda, Belo Horizonte, Brazil).

\section{Fetal gender determination}

For fetal gender estimation 55 Santa Inês ewes, between 49 and 59 days pregnant, were used. Gestational age was calculated considering mating day as day zero of pregnancy. A fetus was diagnosed as female when the genital tubercle was seen near the tail (Figure 1) and as male when the genital tubercle was seen near the umbilical cord insertion in the abdomen (Figure 2). Images of all exams were recorded on DVD to allow posterior analysis. All exams were performed by the same operator.

After birth, the actual lamb gender was checked to confirm the results of the ultra-sound estimation.

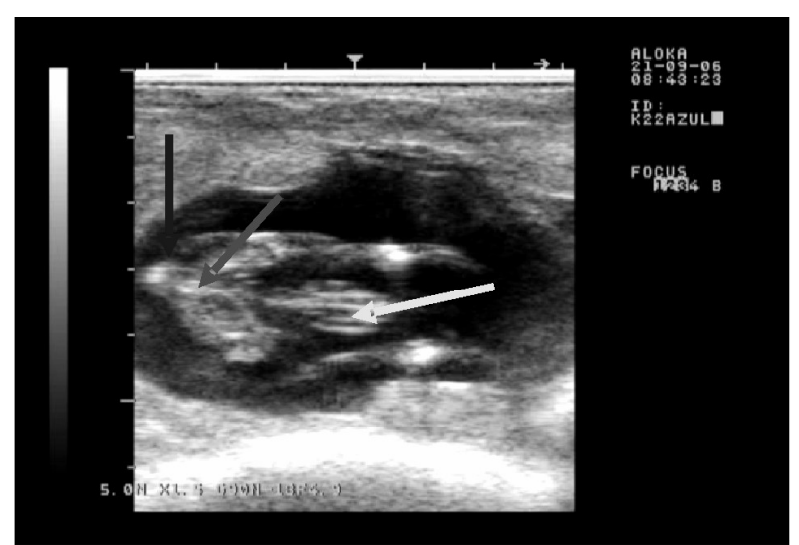

Figure 1 - Female fetus with tail (black arrow) allowing genital tubercle visualization (graw arrow) right bellow it. Note the umbilical cord image (white arrow)

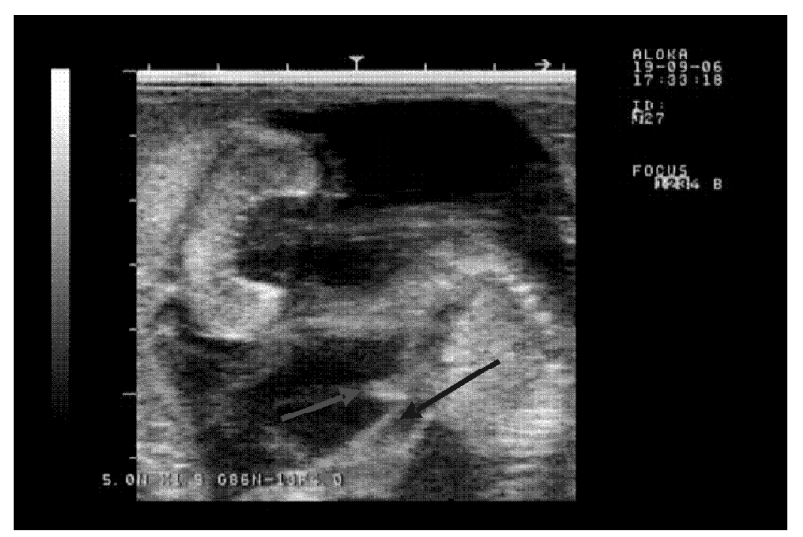

Figure 2 - Sagital plane of 56 days old male fetus. Note the hyperechogenic images of the genital tubercle (gray arrow) and that of the umbilical cord (black arrow) cranially.

\section{Fetal Quantification}

A total of 105 ewes were used (92 Santa Inês and 13 Bergamácia females). Ewes were diagnosed at near 35 days of gestation. The same ultra-sound equipment was used as described for fetal gender estimation.

Ewes were diagnosed pregnant after fetal presence and cardiac activity were detected. Furthermore, the remaining sections of the uterus were screened for the evaluation of additional fetuses and consequent estimation of the total fetal number.

Fetal loss was determined by the difference in the number of lambs born and the number of fetuses estimated by the ultrasound exams divided by the total number of lambs born and multiplied by a hundred. 


\section{Statistical Analysis}

The experimental was designed in a completely randomized scheme. Data were submitted to chisquare analysis $\left(\chi^{2}\right)$ or Fisher Test, at a 5\% significance level under the PROC FREQ statistical package of SAS ${ }^{\circledR}$ (Der and Everitt, 2002).

\section{RESULTS AND DISCUSSION}

Pregnancy rates were not different $(\mathrm{P}>0.05)$ between breeds. Overall fetal loss was $9.9 \%$ (9/91) and 18.1\% (2/11) and $8.7 \%$ (7/80) for Bergamácia and Santa Inês, respectively.

There was $100 \%$ accuracy for the ultra-sonography based estimates, so that, no ewe was diagnosed as nonpregnant. This occurred because the pregnancy diagnose in ewes at 35 days of gestation is facilitated by the large amount of fluid within the uterus, which forms a well characterized non-echogenic image, besides the visualization of the fetus itself and of the heart beats (Santos, 2004).

In the fetal quantification estimation exams, eight double and one triple gestations were erroneously diagnosed, or an $11 \%$ error rate. There was one gestation diagnosed as double, which actually yielded the birth of a single offspring. However, this error could have occurred from fetal death during gestation as related by White et al (1984) Gearhart et al (1988) and Santos et al (2006a and
2006 b). Considering this latter event, the accuracy error rate for fetal quantification increases to $12 \%$ (Table 2).

This apparently high error rate (White et al, 1984) may have occurred, in part, by the limited operator experience (Haibel, 1990) together with the difficulty in obtaining the image of all fetuses during the exam.

For this reason, in the ultra-sound exam 52 single pregnancies were diagnosed, but after lambing, 53 were detected, therefore, a $98.1 \%$ accuracy in the quantification of single fetus pregnancies (Table 2). Out of 28 double pregnancies, only 20 were diagnosed correctly, or, eight pregnancies were wrongly diagnosed as single, hence, of the 16 lambs originating from double pregnancies, only 8 were visualized and, therefore, quantified during the ultrasound exam. Since there was only one triple gestation, erroneously diagnosed as single, it was not possible to run statistics on it.

The only ewe that showed less tolerance to the ultrasound examination was the one bearing three fetuses. This ewe only allowed a one minute exam and this may have been insufficient time for an optimal genital tubercle visualization, resulting in the wrong estimate. Considering this specific situation, one may conclude that exam tolerance is another factor leading to fetal quantification and gender estimation errors. The remaining wrong diagnosis $(n=8)$ were, in part, due to the uterus anatomical positioning further ventrally in the abdominal cavity, making it more difficult to adequately place the transducer

Table 1 - Herd data: breed, gestation rate and fetal loss rate expressed numerically and as percentages in parenthesis.

\begin{tabular}{cccc}
\hline & \multicolumn{3}{c}{ Number of ewes/total (percentage) } \\
\hline Diagnostic results & Bergamácia & Santa Inês & Total \\
\hline Totals per breed & $13 / 105(12.4 \%)$ & $92 / 105(87.6 \%)$ & 105 \\
Pregnant ewes & $11 / 13(84.6 \%)$ & $80 / 92(87.0 \%)$ & $91 / 105(86.6 \%)$ \\
Non-pregnant ewes & $0(0.0 \%)$ & $14 / 92(15.2 \%)$ & $14 / 105(13.4 \%)$ \\
Fetal loss & $2 / 11(18.1 \%)$ & $7 / 80(8.7 \%)$ & $9 / 91(9.9 \%)$ \\
Ewes lambing & $9 / 11(81.8 \%)$ & $73 / 80(91.2 \%)$ & $82 / 91(90.1 \%)$ \\
\hline
\end{tabular}

Table 2 - Fetal quantification estimate accuracy in relation to pregnancy type.

\begin{tabular}{ccccc}
\hline Gestation type & $\begin{array}{c}\text { Number of pregnancies } \\
\text { estimated by ultra-sound }\end{array}$ & $\begin{array}{c}\text { Actual } \\
\text { pregnancies }\end{array}$ & Correct estimates & Incorrect estimates* $^{*}$ \\
\hline Single & 52 & 53 & $52 / 53(98.1 \%)$ & $1 / 53(1.9 \%)^{\mathrm{a}}$ \\
Double & 20 & 28 & $20 / 28(71.5 \%)$ & $8 / 28(28.5 \%)^{\mathrm{b}}$ \\
Triple** & 0 & 1 & $0 / 1(0)$ & $1 / 1(100.0 \%)$ \\
Total & 72 & 82 & $72 / 82(88.0 \%)$ & $10 / 82(12.0 \%)$ \\
\hline
\end{tabular}

\footnotetext{
* Numbers with different superscript letters within the column differ $(\mathrm{P}<0.05)$ by the chisquare test.
}

** It was not possible to compare this type of pregnancy due to its insufficient frequency. 
and generate the desired image. In these cases, it was necessary to lift the abdomen with a belt, which was not always efficient.

It was demonstrated that the accuracy of fetal quantification was greater $(\mathrm{P}<0.05)$ in ewes bearing a single fetus $(98.1 \%)$ compared to double pregnancy ewes (71.5). Since Bergamácia ewes had had only single pregnancies, it was not possible to evaluate the effect of breed on fetal quantification accuracy (Table 2).

It was possible to diagnose 69 fetuses in the 55 ewes studied. Of these 69 fetuses, it was possible to estimate gender in $87 \%(\mathrm{n}=60)$, only (Table 3$)$. Burstel (2002) and Coubrough \& Castell (1998) were not able to estimate the fetal gender in only $7 \%$ of fetuses examined, recalling that the first author performed more than one exam on each animal and, the latter, when not able to visualize the fetus, performed the exam with the ewe lying on her dorsal region. Ninety percent (54/60) fetal gender estimates were correct. A similar accuracy was reported by Santos, (2005a).

The field diagnose was not significantly different from the ones performed after recorded DVD images (Table 3 ). With the exception of one exam, all results in the field examinations were identical to the DVD ones, contrarily to what Merkt (1999) found in mares. This occurred because this experiment, besides having adopted external light control and placing the ultrasound unit at the level of the operator's eyes, was performed with ewes which tolerated the procedures well for the most part. As suggested by Curran \& Ginther (1989), Ginther, (1995) and Marie e et al (2002), these parameters together with patience, experience and operator's ability, contribute to the exam reliability.

Table 3 - Fetal gender estimation results.

\begin{tabular}{lcc}
\hline & \multicolumn{2}{c}{$\begin{array}{c}\text { Number of exams } \\
\text { (Percentages) }\end{array}$} \\
\cline { 2 - 3 } Diagnosis & DVD & Campo \\
\hline $\begin{array}{l}\text { With gender } \\
\text { estimation }\end{array}$ & $60(87.0 \%)$ & $60(87.0 \%)$ \\
$\begin{array}{l}\text { Without gender } \\
\text { estimation }\end{array}$ & $9(13.0 \%)$ & $9(13.0 \%)$ \\
Correct & $54(90.0 \%)$ & $53(88.3 \%)$ \\
Incorrect & $6(10.0 \%)$ & $7(11.7 \%)$ \\
Total & 69 & 69 \\
\hline
\end{tabular}

Fetal gender estimation accuracy did not differ $(\mathrm{P}=0.77)$ within the gestational interval of 49 to 59 days. Although it is only a 10 days period, it ensures sufficient error margin for the exam reliability.
Since there was a greater female proportion (17\%) without gender estimation compared to males $(7.1 \%)$ (Table 4 ), there was greater difficulty for genital tubercle visualization when it was located near the tail, possibly due to the fetal position, which did not allow for a better image of the pelvic region. A few authors also related this difficulty and greater errors when diagnosing female fetuses, due to this same reason as well as the presence of the tail itself which could block or interfere with the genital tubercle image (Coubrough \& Castell, 1998; Merkt, 1999; Marie et al, 2002; Bürstel et al, 2002; Santos et al 2005a).

Table 4 - Fetal gender effect on diagnostic accuracy of ultrasound fetal gender estimation

\begin{tabular}{ccccc}
\hline Gender & $\begin{array}{c}\text { Lambs } \\
\text { born and } \\
\text { diagnosed }\end{array}$ & $\begin{array}{c}\text { Without } \\
\text { diagnosis }\end{array}$ & $\begin{array}{c}\text { Correct } \\
\text { estimate }\end{array}$ & $\begin{array}{c}\text { Incorrect } \\
\text { estimate }\end{array}$ \\
\hline Males & 28 & $\begin{array}{c}2 / 28 \\
(7.1 \%)^{\mathrm{a}}\end{array}$ & $\begin{array}{c}23 / 28 \\
(82.1 \%)\end{array}$ & $\begin{array}{c}3 / 28 \\
(10.7 \%)\end{array}$ \\
Females & 41 & $\begin{array}{c}7 / 41 \\
(17.0 \%)^{\mathrm{b}}\end{array}$ & $\begin{array}{c}31 / 41 \\
(75.6 \%)\end{array}$ & $\begin{array}{c}3 / 41 \\
(7.3 \%)\end{array}$ \\
\hline
\end{tabular}

Values followed by distinct letters within rows differ $(\mathrm{P}<0.05)$ by the Fisher Test.

\section{CONCLUSIONS}

It is possible to quantify fetal number and test for pregnancy at 35 days of gestation in ewes.

Fetal gender estimation is a procedure that may be incorporated to the routine of field sheep reproductive examinations with an accuracy rate of nearly $100 \%$ in single pregnancies, without the need of recording images.

In sheep, fetal quantification is a determining factor in fetal gender estimation with double pregnancies.

\section{BIBLIOGRAPHYCAL REFERENCES}

ANDRADE, J. C. O.; GUIDO, S. I.; SOUSA, B. P. A. Sexagem fetal em ovinos. Acta Sciantiae Veterinariae, Porto Alegre, v. 32, p. 185, abril, 2004.

BÜRSTEL, D.; MEINECKE-TILLMAN, S.; MEINECKE, B. Ultrasonographic diagnosis of fetal sex in small ruminants bearing multiple fetuses. The Veterinary Record, London, v. 23, p. 635-636, november 2002.

COUGHBROUGH, C. A.; CASTELL, M. C. Fetal sex determination by ultrasonically locating the genital tubercle in ewes. Theriogenology, Worburn, v. 50, n. 2 , p. 263-267, july, 1998. 
CURRAN, S.; GINTHER, O. J. Ultrasonic diagnosis of equine fetal sex by location of the genital tubercle. Journal Equine Veterinary Science, Colorado, v. 9, n. 2, p. 77-83, january/february, 1989.

DANTAS, A. F.; PEREIRA FILHO, J. M.; SILVA, A. M. DE A.; SANTOS, E. M. DOS, SOUSA, B. B. DE, CEZAR, M. F. Características da carcaça de ovinos Santa Inês terminados em pastejo e submetidos a diferentes níveis de suplementação. Ciência e Agrotecnologia. Lavras, v. 32, n. 4, p. 1280-1286, jul./ago., 2008.

DER, G.; EVERITT, B. S. A handbook of statistical analyses using SAS. 2. ed. London: Chapman \& Hall, 2002. $360 \mathrm{p}$.

GEARHART, M. A.; WINGFIELD, W. E.; KNIGHT, A. P.; SMITH, J. A.; DARGATZ, D. A.; BOON, J. A.; STOKES, C. A. Real-time ultra-sonography for determining pregnancy status and viable fetal numbers in ewes. Theriogenology, Worburn, v. 30, n. 2, p. 323349 , august, 1988.

GINTHER, O. J. Ultrasonic diagnosis of fetal sex. In: GINTHER, O.J. Ultrasonic imaging and animal reproduction: horses. Book 2. - Madison, Equiservices, 1995, p. 236-246.

HAIBEL, G. K. Use of ultra-sonography in the reproductive management of sheep and goat herds. Veterinary. Clinics of North America Food Animal Practice, Philadelphia, v. 3, n.3, p. 597-613, march, 1990.

MARI, G.; CASTAGNETTI, C.; BELUZZI, S. Equine fetal sex determination using a single ultrasonic examination under farm conditions. Theriogenology, Worburn, v. 58, p. 1237-1243, october, 2002.

MERKT, H.; MOURA, J. C. de A.; JÖCHLE, W. Gender determination in equine fetuses between 50 and 90 days of gestation. Journal of Equine Veterinary Science, Colorado, v. 19, n. 2, p. 90-94, february, 1999.

OLIVEIRA, M. A. L.; SANTOS, M. H. B.; MORAES, E. P. B. X.; MOURA, R. T. D.; CHIAMENTI, A.; RABELO, M. C.; BEZERRA, F. Q. G.; LIMA, P. F. Early identification of fetal sex and determination of the genital tubercle migration day in dairy goats using ultrasound. Acta Scientiae Veterinariae, Porto Alegre, v. 32, p. 459, maio, 2005.

SANTOS, M. H. B.; GONZALEZ, C. I. M.; BEZERRA, F. Q. G.; NEVES, J. P.; REICHENBACH, H. D.; LIMA, P. F.; OLIVEIRA, M. A. L. Sexing of Dorper sheep fetuses derived from natural mating and embryo transfer by ultra-sonography. Reproduction Fertility and Development, Austrália, v. 19, p. 366-369, january, 2007a.

SANTOS, M. H. B.; MORAES, E. P. B. X.; GUIDO, S. I.; BEZERRA, F. Q. G. B.; MELO, A. N.; LIMA, P. F.;

OLIVEIRA, M. A. L. Fetal sexing in Santa Inês ewes by ultra-sonography. Ciência Rural, Santa Maria, v. 36, n. 2, p. 573-578, march-april 2006.

SANTOS, M. H. B.; MORAES, E. P. B. X.; GUIDO, S. I.; GONDIM, F. Q. B.; LIMA, P. F.; FREITAS, V. J. F.; OLIVEIRA, M. A. L. Identificação do sexo de fetos em úteros de cabras e ovelhas utilizando a ultra-sonografia. Ciência Veterinária nos Trópico, Recife, v. 8, n. 1/2/3, p. 65-69, janeiro/dezembro 2005a.

SANTOS, M. H. B.; MORAES, E. P. B. X.; RABELO, M. C.; MELO, A. N.; LIMA, P. F.; OLIVEIRA, M. A. L. Fetal sexing by ultra-sonography in ewe of Santa Inês breed. Acta Scientiae Veterinariae, Porto Alegre, v. 32, p. 247, outubro, 2005b.

SANTOS, M. H. B.; RABELO, M. C.; GUIDO, S. I.; TORREÃO, J. N. C.; LOPES JÚNIOR, E. S.; FREITAS, V. J. F.; LIMA, P. F. de; OLIVEIRA, M. A. L. Determination of the genital tubercle migration period in Morada Nova sheep fetuses by ultra-sonography. Reproduction of Domestic Animal, Berlin, v. 41, 2007b. IN PRESS

SANTOS, M. H. B; OLIVEIRA, M.A L.; MORAES, E.P.B.X.; CHALHOUB, M.; BICUDO, S.D. Diagnóstico de gestação por ultra-sonografia em tempo real. In: SANTOS, M.H.B.; OLIVEIRA, MAL; LIMA, PF Diagnóstico de gestação na cabra e na ovelha. São Paulo: Varela, 2004. p. 97-116.

WHITE, I. R.; RUSSEL, A. J. F.; FOWLER, D. G. Real-time ultrasonic scanning in the diagnosis of pregnancy and the determination of fetal numbers in sheep. The Veterinary Record, London, v. 115, n. 18, p. 140-143, august 1984. 